\title{
Den brysomme samvittigheten
}

\author{
En kollega har mistet fastlegejobben av samvittighetsgrunner. Saken bør lede til diskusjon om hvem som \\ skal definere fastlegerollen, om det liberale dilemmaet og om verdien av moralsk integritet.
}

En polsk kollega ble nylig sagt opp fra sin stilling som fastlege fordi hun ikke vil sette inn spiral (1). Virkningsmekanismene ved spiral er ikke fullt ut forstått, men den preventive virkningen av både kobberspiral og hormonspiral kan delvis skyldes effekter på det befruktede egget $(2,3)$, hvilket kan betraktes som en provosert abort på et svært tidlig stadium. Vår kollega er katolikk. Hun anfører at menneskelivet må vernes fra befuktningsøyeblikket og at enhver form for provosert abort er i konflikt med hennes samvittighet og med kirkens lære. Kommunen var informert om dette da hun ble ansatt. Oppsigelsen kom etter et brev fra Helsetilsynet (4), der det ble slått fast at reservasjon mot spiralinnsetting er i strid med fastlegeforskriften (5).

Dermed ble den brysomme samvittigheten aktuell igjen. Diskusjonen om reservasjon mot henvisning til abort ebbet ut da det ble bestemt at kvinnen selv kan begjære provosert abort fra en gynekologisk avdeling (5). Men noen løsning på samvittighetsdilemmaet var bestemmelsen ikke snarere ble de vanskelige spørsmålene tilslørt av politisk hestehandel. Denne saken kan gi oss en ny inngang til en uunngåelig prinsippdebatt med tre sentrale komponenter.

\section{Kampen om definisjonsmakten}

Helsetilsynets uttalelse slår fast at det er myndighetene som definerer fastlegenes virksomhet (4). Satt på spissen: Fastlegen må utføre de oppgaver som staten - og dermed flertallet i befolkningen - fastsetter. Resonnementet kan synes plausibelt, men har flere problematiske sider.

For det første: Hvordan skal vi forholde oss til eventuelle statlige vedtak som i større grad utfordrer innarbeidede profesjonsverdier? Hva om staten vedtar rett til eutanasi? Eller retten til å få utført mannlig omskjæring på fastlegekontoret? Er statlige forordninger legitime så lenge de bare vekker anstøt hos et lite mindretall av kollegene?

For det andre: Er statens flertallsbaserte beslutninger den eneste relevante rettesnoren i et demokrati? Mange lokalsamfunn slår ring om sine «reservasjonsleger» (6) er det legitimt at denne lokale støtten blir overkjørt av storsamfunnets oppfatninger?

For det tredje: Er ikke statens overtakelse av definisjonsmakten bare tilsynelatende, fordi den nødvendigvis må bygge på medisinsk innsikt? I den konkrete saken skriver Helsetilsynet at «innsetting av spiral (...) er allmennlegetjenester som skal inngå i det helhetlige tilbudet som fastlegene skal tilby» (4). Men spiral står ikke nevnt i fast- legeforskriften - Helsetilsynet baserer seg på hva som er vanlig allmennlegepraksis, noe som altså defineres av fastlegene selv. Selv om flertallet mener at spiralinnsetting hører til grunnkompetansen, er det ingen naturlov som sier at det må tilbys av alle.

\section{Diskriminering \\ og det liberale dilemma}

Vår polske kollegas holdning er eksempel på en mer omfattende samfunnsutfordring: Hvordan skal man forholde seg til at stadig flere har et verdisyn som er begrunnet på andre måter enn gjennom henvisning til statens liberale idealer? I spørsmålet om spiralinnsetting er vår polske kollega lojal mot den katolske kirkes normsystem fremfor den norske statens - men skal hun av den grunn ha yrkesforbud som fastlege?

Problemstillingen er en variant av det liberale dilemma (7): Dersom hun får fortsette som fastlege, har staten ansatt en person som gjennom sin moralske overbevisning motarbeider statens liberale idealer. Dersom hun ikke får fortsette, er det staten selv som bryter med sine egne liberale idealer, fordi den da kan sies å være diskriminerende og intolerant.

Dette liberale dilemmaet kan ikke løses ved at man later som om det ikke finnes. Men det kan være en hjelp å avlive myten om en nøytral posisjon, altså at medisinsk virksomhet kan frikobles normative vurderinger. Flertallet av norske legers standpunkt til spiralinnsetting er selvsagt ikke mer «nøytralt» enn standpunktet til vår polske kollega - det er bare annerledes.

\section{Samvittighetsfrihet og moralsk integritet}

I forbindelse med landsstyredebatten om reservasjonsadgang i 2013 kunne en høringsgruppe - som var splittet på mange områder - likevel enes om følgende: «Medisinsk praksis skal baseres på humanistiske verdier, med særlig ansvar for de svakeste. Det er viktig at helsepersonell har mot til å reagere mot handlinger som strider mot grunnleggende verdier, som for eksempel å ta liv, utføre helsetjenester som har til hensikt å skade ...» (8).

Vår polske kollega vil mene at det er nettopp dette hun har gjort: Den befruktede eggcellen er den svakeste part, dette livet må vernes mot skade fra en spiral. Flertallet deler ikke hennes grunnpremiss: At en befruktet eggcelle er et liv på linje med en født person. Likevel går det kanskje an å verdsette hennes moralske integritet som en selvstendig verdi? Kanskje er det sunt for flertallet å bli grunnleggende utfordret?
Kanskje dette er en umistelig del av demokratiet?

Filosofen Jürgen Habermas - selverklært ateist - mener $i$ alle fall det. Det liberale samfunn, skriver han, må anerkjenne blant annet samvittighet og religiøse tradisjoner som fullt ut gyldige kilder for moralske oppfatninger (9). Det er en berikelse, ikke et problem, at enkeltpersoner har andre moralske kilder enn flertallet. En slik grunnholdning vil være i det liberale samfunns egen interesse.

La det stå som en oppfordring til den kommende meningsutvekslingen.

\section{Vegard Bruun Wyller}

brwylle@online.no

Vegard Bruun Wyller (f. 1972) er professor og overlege ved Akershus universitetssykehus og medisinsk redaktør i Tidsskriftet.

Forfatter har fylt ut ICMJE-skjemaet og oppgir ingen interessekonflikter.

Litteratur

1. Magnus PC, Skjelbred GE. Oppsagt reservasjonslege saksøker kommunen. NRK Telemark 9.3.2016. www.nrk.no/telemark/oppsagtreservasjonslege-i-telemark-saksokerkommunen-1.12844713 (14.3.2016).

2. Stanford JB, Mikolajczyk RT. Mechanisms of action of intrauterine devices: update and estimation of postfertilization effects. Am J Obstet Gynecol 2002; 187: 1699-708.

3. ESHRE Capri Workshop Group. Intrauterine devices and intrauterine systems. Hum Reprod Update 2008; 14: 197-208.

4. Fastleges reservasjonspraksis - kommunens ansvar for fastlegeordningen. Brev fra Statens helsetilsyn til Sauherad kommune v/rådmannen 26.1.2015. Oslo: Statens helsetilsyn, 2015.

5. Forskrift om fastlegeordning i kommunene. FOR-2012-08-29-842. https://lovdata.no/ dokument/SF/forskrift/2012-08-29-842 (14.3.2016).

6. Eliassen H, Gjestland HS. Må gå på grunn av spiralnekt - får massiv støtte. NRK Sørlandet 23.2.2015. www.nrk.no/sorlandet/ ma-ga-pa-grunn-av-spiralnekt-_-far-massivstotte-1.12225697 (14.3.2016)

7. Skjervheim H. Det liberale dilemma og andre essay. Oslo: Tanum, 1968.

8. Legeforeningen. Reservasjonsadgang, rapport fra arbeidsgruppe. Landsstyremøte 2013. http://legeforeningen.no/Legeforeningen-mener/ Horinger/Landsstyresak----Reservasjonsadgangrapport-fra-arbeidsgruppe/ (14.3.2016).

9. Habermas J. Førpolitiske grunnlag for den demokratiske rettsstat? I: Habermas J, Ratzinger J. Sekulariseringens dialektikk. Om fornuft og religion. Oslo: St. Olav forlag, 2008.

Mottatt 23.3. 2016 og godkjent 30.3. 2016. Redaktør: Ketil Slagstad.

Publisert først på nett. 